\title{
PERANCANGAN SISTEM INFORMASI MONITORING PEMBAYARAN PIUTANG PADA PT WINGOH ALBINDO
}

\author{
Sri Ayu Wulandari ${ }^{1}$, Mintauli Debataraja ${ }^{2}$, Warseno $^{3}$ \\ Mahasiswa Universitas Raharja ${ }^{1}$, Dosen Akuntansi Universitas Raharja ${ }^{2}$, Dosen Akuntansi \\ Universitas Raharja ${ }^{3}$ \\ Jl. Jend. Sudirman No. 40, Modern Cikokol, Tangerang
}

Email:.sri.ayu@raharja.info ${ }^{1)}$, mintauli@raharja.info ${ }^{2)}$, warseno@raharja.info ${ }^{3)}$

\begin{abstract}
ABSTRAK
Penggunaan kemajuan teknologi di bidang teknologi informasi sangat strategis untuk membantu menyelesaikan masalah perusahaan, namun di PT Wingoh Albindo belum menggunakan penerapan berbasis web, dalam monitoring pembayaran piutang masih menggunakan microsoft excel sehingga mengalami kesulitan dalam membedakan piutang yang sudah dan yang akan jatuh tempo. Oleh sebab itu, penelitian ini bertujuan untuk mempermudah perusahaan dan staff A.R (Account Receivable) yang bekerja di dalam-nya untuk dapat memonitoring pembayaran piutang dari customer. Penelitian ini dilakukan dengan metode analisa SWOT, perancangan sistem dengan menggunakan UML (Unified Modelling Language) untuk menggambarkan secara visualisasi. Untuk bahasa pemrograman yang dipakai adalah PHP (Hypertext Preprocessor), database server dengan MySQL, sublime text 2, framework Codeigniter dan web server dengan XAMPP. Dengan sudah adanya sistem monitoring pembayaran piutang ini akan memudahkan staff A.R (Account Receivable) untuk melihat dan memantau piutang customer dalam perusahaan dan juga memudahkan dalam membuat laporan pembayaran piutang serta juga menghasilkan laporan yang cepat dan akurat.
\end{abstract}

Kata kunci : Sistem, Informasi, Monitoring, Piutang

\begin{abstract}
The use of technological advances in the field of information technology is very strategic to help solve company problems, but PT Wingoh Albindo has not yet used web-based applications, in monitoring accounts receivable payments still using Microsoft Excel so that it has difficulty distinguishing between past and maturing receivables. Therefore, this study aims to facilitate the company and the A.R (Account Receivable) staff who work in it to be able to monitor the payment of receivables from customers. This research was conducted with the SWOT analysis method, system design using UML (Unified Modeling Language) to describe the visualization. The programming language used is PHP (Hypertext Preprocessor), database server with MySQL, sublime text 2, Codeigniter framework and web server with XAMPP. With the existence of a receivable payment monitoring system, it will make it easier for A.R (Account Receivable) staff to view and monitor customer receivables within the company and also make it easier to create accounts receivable payment reports and also produce fast and accurate reports.
\end{abstract}

Keywords: System, Information, Supervision, Receivables 


\section{PENDAHULUAN}

Teknologi sistem informasi yang berkembang cukup pesat dalam bidang bisnis dan lainnya saat ini sangat berpengaruh dan memegang peranan penting dalam berbagai hal di seluruh dunia. Didalam dunia bisnis teknologi informasi sangatlah penting untuk dapat menentukan kemajuan di suatu perusahaan dan juga sebagai hal yang utama dalam menunjang semua sistem yang sedang berjalan. Dibutuhkan teknologi yang sangat cepat serta efisien dalam pengumpulan, penyimpanan dan pengolahan data untuk meningkatkan penjualan.

Penerapan sistem informasi di berbagai bidang saat ini juga banyak digunakan oleh berbagai macam badan usaha atau perusahaan. Dengan adanya sistem informasi memudahkan perusahaan dalam mengolah data serta seluruh kegiatan perusahaan agar dapat termonitoring oleh pihak perusahaan. Begitupun dengan bagian keuangan sistem informasi menjadi acuan dalam mengolah data keuangan perusahaan. Salah satu contoh perkembangan sistem informasi akuntansi online berbasis web versi 2.0 dimana sistem ini memperlihatkan dan memberikan kemudahan untuk mengelola uang masuk juga uang keluar dari kas perusahaan. (Nur Azizah, Dedeh Supriyati, Siti Fairuz Mustapha, Holly Yang.2017:44-49).

Selain itu, masalah yang terjadi bukan hanya terhambat namun akan ada masalah lain yang timbul seperti pendapat dari Klijucnikov Aleksandr, Kozubikova Ludmila, Sopkova Gabriela (2017:45-61) "menyatakan bahwa masalah disiplin pembayaran akan sangat terkait dengan daya saing perusahaan. Apabila ada keterlambatan dalam pembayaran, baik pembayaran piutang ataupun pembayaran lainnya dapat menimbulkan resiko kebangkrutan dan penurunan daya saing.

\section{METODE PENELITIAN}

Metode penelitian merupakan suatu tata cara atau kegiatan pelaksanaan penelitian rangka untuk mengumpulkan informasi atau data serta melakukan investigasi terhadap data yang telah didapatkan tersebut. yang didasari oleh asumsi-asumsi dasar, pandanganpandangan filosofis dan ideologis, pertanyaan dan isu-isu yang dihadapi. Suatu penelitian mempunyai rancangan penelitian tertentu. Rancangan ini menggambarkan prosedur atau langkah-langkah yang harus ditempuh, waktu penelitian, sumber data dan kondisi arti untuk apa data dikumpulkan dan dengan cara bagaimana data tersebut dihimpun dan diolah untuk dianalisa dalam pembuatan laporan.

\subsection{Metode Observasi (Observasi Research)}

Metode observasi dilakukan dengan cara mendatangi langsung PT Wingoh Albindo guna memperoleh data-data yang diperlukan dengan melakukan pengamatan dan melaksanakan pencatatan secara sistematis mengenai monitoring pembayaran piutang yang ada di PT Wingoh Albindo.

\subsection{Metode Wawancara (Interview Research)}

Metode wawancara yang dilakukan dengan cara tanya jawab langsung dengan stakeholder selaku penanggung jawab di PT Wingoh Albindo guna mendapatkan informasi berkaitan dengan penelitian ini dalam melengkapi hasil observasi, penulis melakukan metode wawancara atau tanya jawab untuk mendapatkan suatu data.

\subsection{Metode Studi Pustaka (Studi Literatur)}

Setelah melakukan observasi dan wawancara penulis juga mencari data dengan cara studi pustaka. Pada metode ini peneliti melakukan studi pustaka untuk melengkapi data-data yang lebih akurat dengan cara mengumpulkan data teoritis yang bersumber dari hasil kuliah, 
jurnal literature dari koleksi buku perpustakaan, serta sumber-sumber lain yang berkaitan dengan penyusunan skripsi tersebut. Sehingga peneliti mendapatkan gambaran secara teoritis yang berguna untuk membantu penganalisaan dan perancangan maupun penulisan penelitian ini.

\subsection{Metode Analisis Data}

Setelah metode analisa dilaksanakan untuk melengkapi laporan skripsi ini peneliti merancang sistem dengan analisis SWOT yang artinya metode perencanaan strategis yang digunakan untuk mengevaluasi kekuatan.

\section{PEMBAHASAN}

Untuk dapat menggambarkan prosedur secara keseluruhan diperlukan beberapa tahapan analisa sebagai bentuk pengumpulan informasi guna mendapatkan model yang sesuai dengan kebutuhan dan mampu memberikan solusi dengan cepat secara efektif dan efisien, mulai dari tahapan pengumpulan informasi dan kebutuhan, analisis dokumen, rancangan hubungan antar dokumen sampai dengan merancang model diagram database dan model perancangan sistem. Beberapa tahapan yang dimaksud sampai dengan model rancangan yang diciptakan dapat dilihat pada gambar 1,2,3,4,4.

\subsection{Use Case Diagram Prosedur Berjalan}

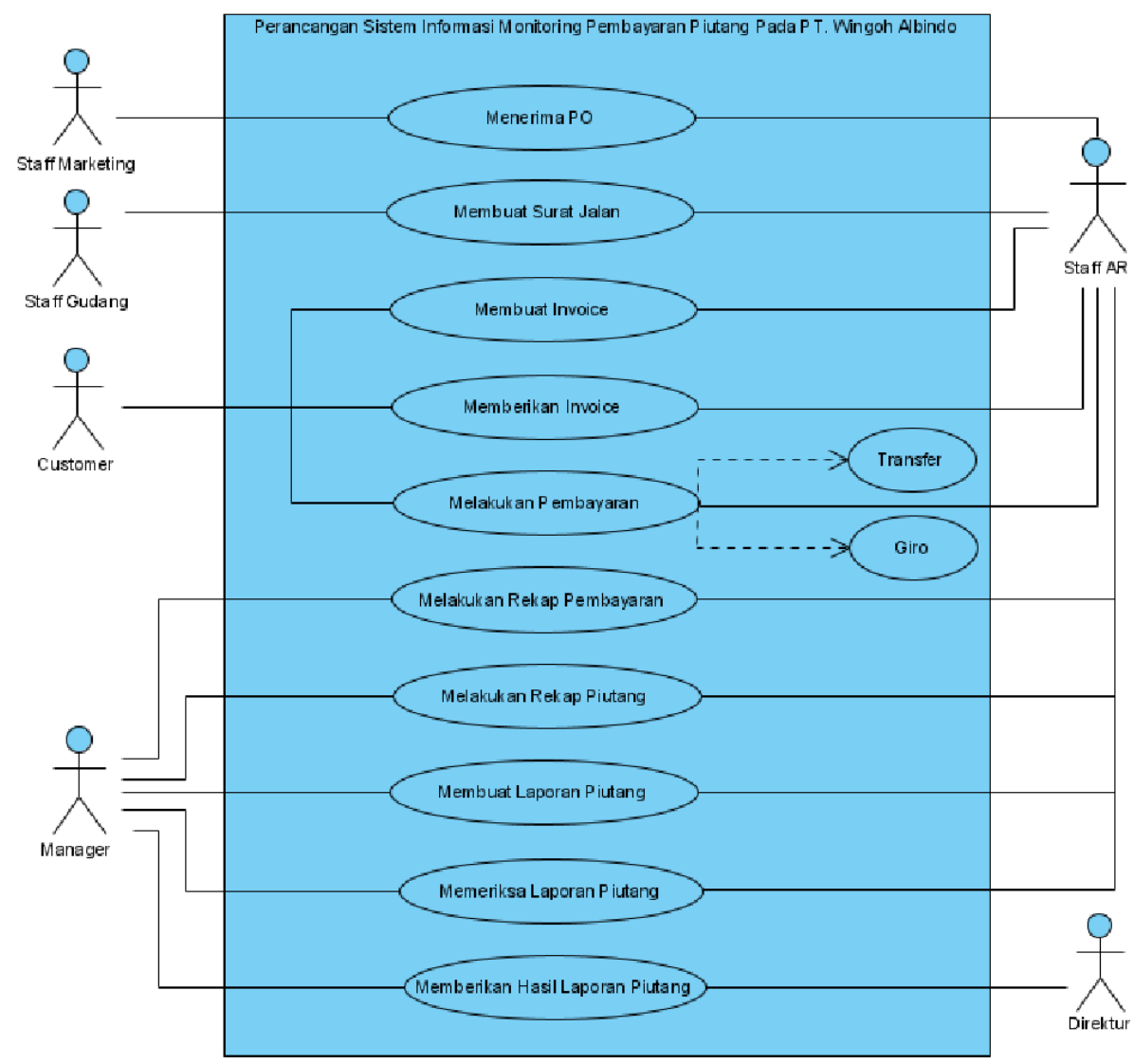

Gambar 1. Use Case Diagram 
Berdasarkan gambar use case Diagram (gambar 1) yang berjalan saat ini sistem mencakup seluruh proses monitoring pembayaran piutang yang saat ini berjalan pada PT Wingoh Albindo. Terdapat enam aktor yang melakukan proses monitoring pembayaran piutang diantaranya: Staff Marketing, Staff Gudang, Staff A.R, Manager dan Direktur

Terdapat juga 10 (sepuluh) use case yang merupakan proses yang terjadi pada sistem berjalan yaitu staf marketing menerima PO untuk customer kepada staff A.R, staff gudang membuat surat jalan untuk Staf A.R yang kemudian akan diberikan kepada sopir untuk pengiriman barang kepada customer, sebelum barang dikirim, staff A.R membuat invoice untuk customer terkait, kemudian staff A.R memberikan invoice melalui kurir untuk customer setelah proses pengiriman barang, setelah barang dikirim dan diterima, kemudian customer melakukan pembayaran hutang mereka kepada perusahaan bisa melalui giro atau transfer, staff A.R kemudian melakukan rekap pembayaran dari customer di perusahaan yang ditujukan untuk Manajer, setelah rekap pembayaran, kemudian staff A.R melakukan kembali rekap piutang perusahaan, kemudian Staff A.R membuat laporan piutang untuk diberikan kepada Manager dan Manager memeriksa laporan piutang yang telah dibuat oleh Staff A.R selanjutnya Manajer memberikan laporan hasil piutang perusahaan kepada Direktur.

\subsection{Activity Diagram Prosedur Berjalan}

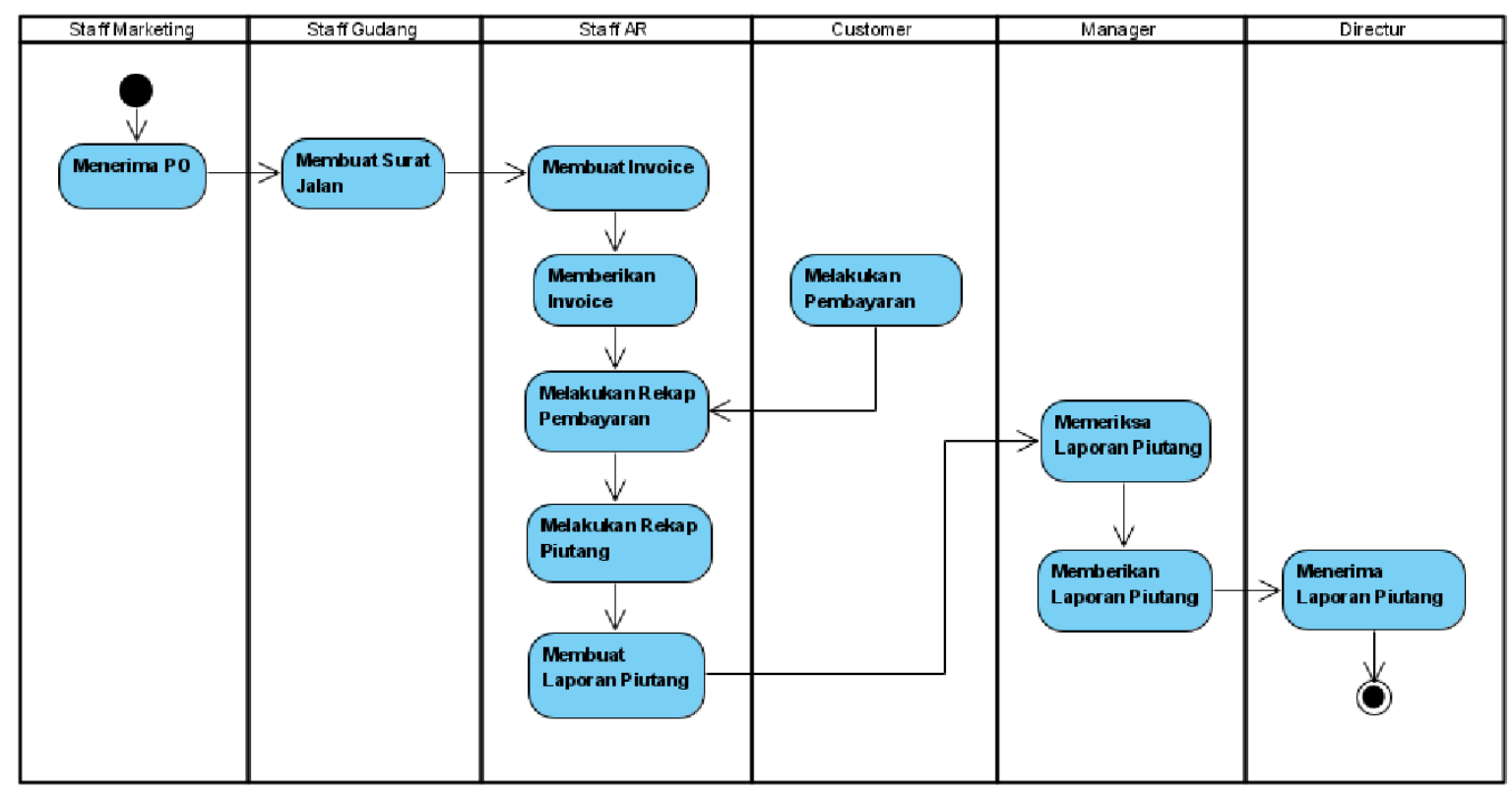

Gambar 2. Activity Diagram

Berdasarkan gambar activity diagram (gambar 2) yang berjalan saat ini sistem mencakup seluruh seluruh monitoring pembayaran piutang. Sistem ini melibatkan 6 (enam) Aktor yaitu, Staff Marketing, Staff Gudang, Staff A.R, Customer, Manager dan Direktur. 


\subsection{Sequence Diagram Prosedur Berjalan}

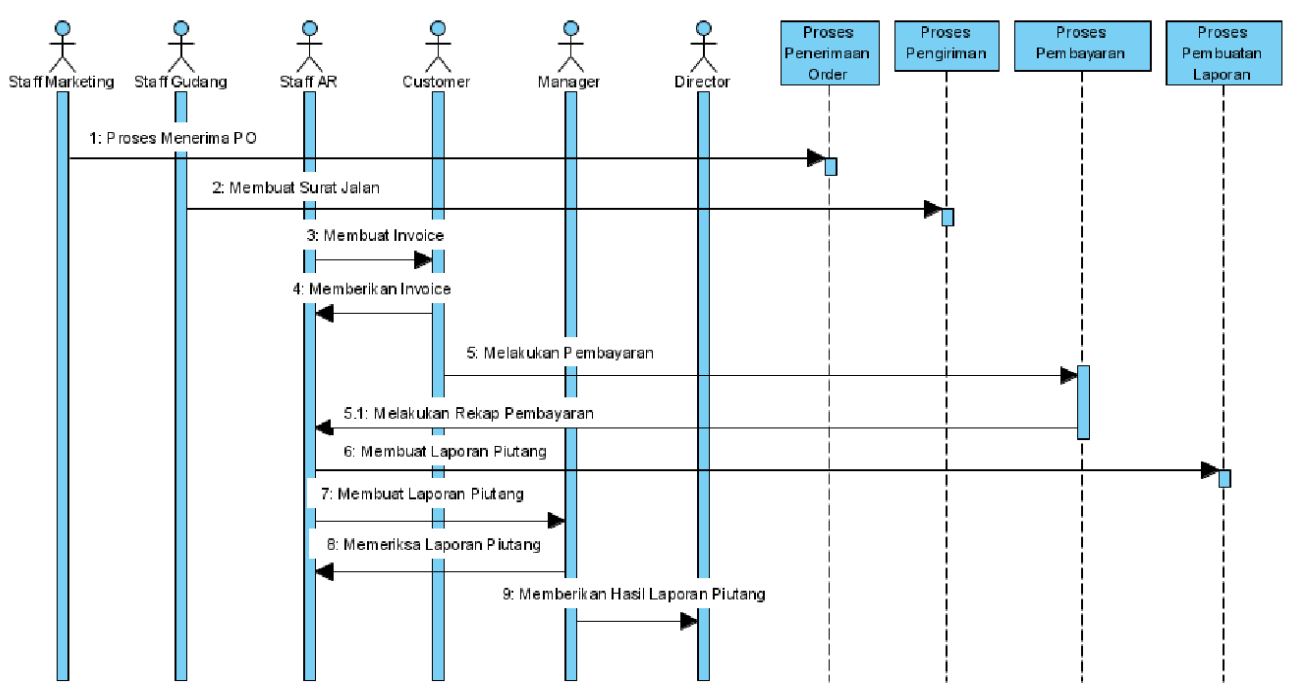

Gambar 3. Sequence Diagram

Berdasarkan gambar sequence diagram (gambar 3) yang berjalan saat ini terlihat Enam aktor yang melakukan kegiatan diantaranya: Staff Marketing, Staff Gudang, Staff A.R, Customer, Manager dan Direktur, yang akan menyelesaikan 5 message spesifikasi dari komunikasi antar objek yang memuat informasi-informasi tentang aktivitas yang terjadi, yaitu penerimaan invoice tagihan, penjadwalan pembayaran, menyiapkan payment, pengajuan cek dan giro, penandatanganan cek dan giro.

Rancangan diatas (gambar 1, 2, 3) merupakan gambaran prosedur yang berjalan dimana pada tahapan ini melibatkan empat lifeline antarmuka yaitu: proses pemesanan, proses pengiriman, proses pembayaran, proses pembuatan laporan dan sembilan message spesifikasi dari komunikasi antar objek yang menurut informasi-informasi yang dilakukan oleh actor tersebut diantaranya: menerima PO, membuat surat jalan, membuat invoice, memberikan invoice, melakukan pembayaran, melakukan rekap pembayaran, melakukan rekap piutang, membuat laporan piutang, memeriksa laporan piutang dan memberikan hasil.

\subsection{Use Case Diagram Usulan}

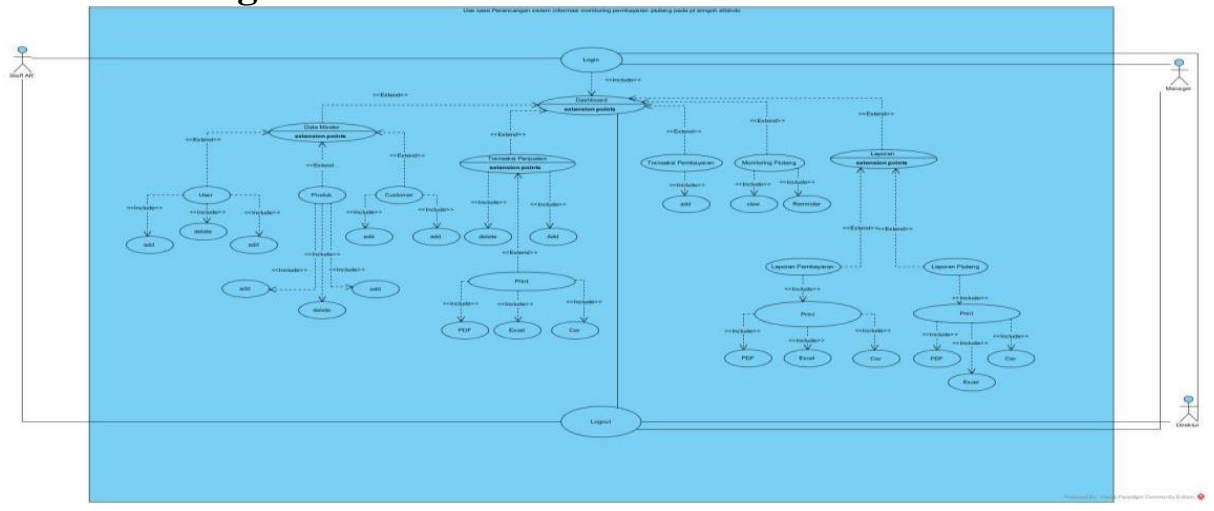

Gambar 4. Use Case Diagram 
Berdasarkan gambar diatas, use case diagram Sistem Monitoring Pembayaran Piutang yang diusulkan terdapat:

1. Satu sistem yang mencakup seluruh kegiatan dalam proses monitoring piutang.

2. Tiga aktor yang melakukan kegiatan yaitu: Staff AR, Manager dan Direktur.

3. Dua puluh use case yang akan dilakukan oleh actor tersebut yaitu: Login, Dashboard, Data Master, Data User, Data User Statement, Data Produk, Data Produk Statement, Data Customer, Data Customer Statement, Transaksi Penjualan, Invoice Statement, Transaksi Pembayaran, Kwitansi Statement, Monitoring Piutang, Laporan, Laporan Pembayaran,

4. Laporan Tujuh Extend yaitu: Data User Statement, Data Produk Statement, Data Customer Statement, Invoice Statement, Kwitansi Statement, Laporan Pembayaran Statement, dan Laporan Piutang Statement.

5. Tujuh Include yaitu: Dashboard, Data Master, Transaksi Penjualan, Transaksi Pembayaran, Monitoring Piutang, Laporan, Logout.

\section{IMPLEMENTASI}

\subsection{Rancangan Basis Data}

Untuk dapat menggambarkan bentuk basis data secara utuh, peneliti menggunakan aplikasi PHP, Database Server MySQL, sublime text 2, framework codeigniter dan web server dengan XAMPP. sebagai bentuk gambaran dasar, dan pada akhirnya bentuk rancangan basis data ini dapat disesuaikan menggunakan apa saja sesuai kebutuhan.

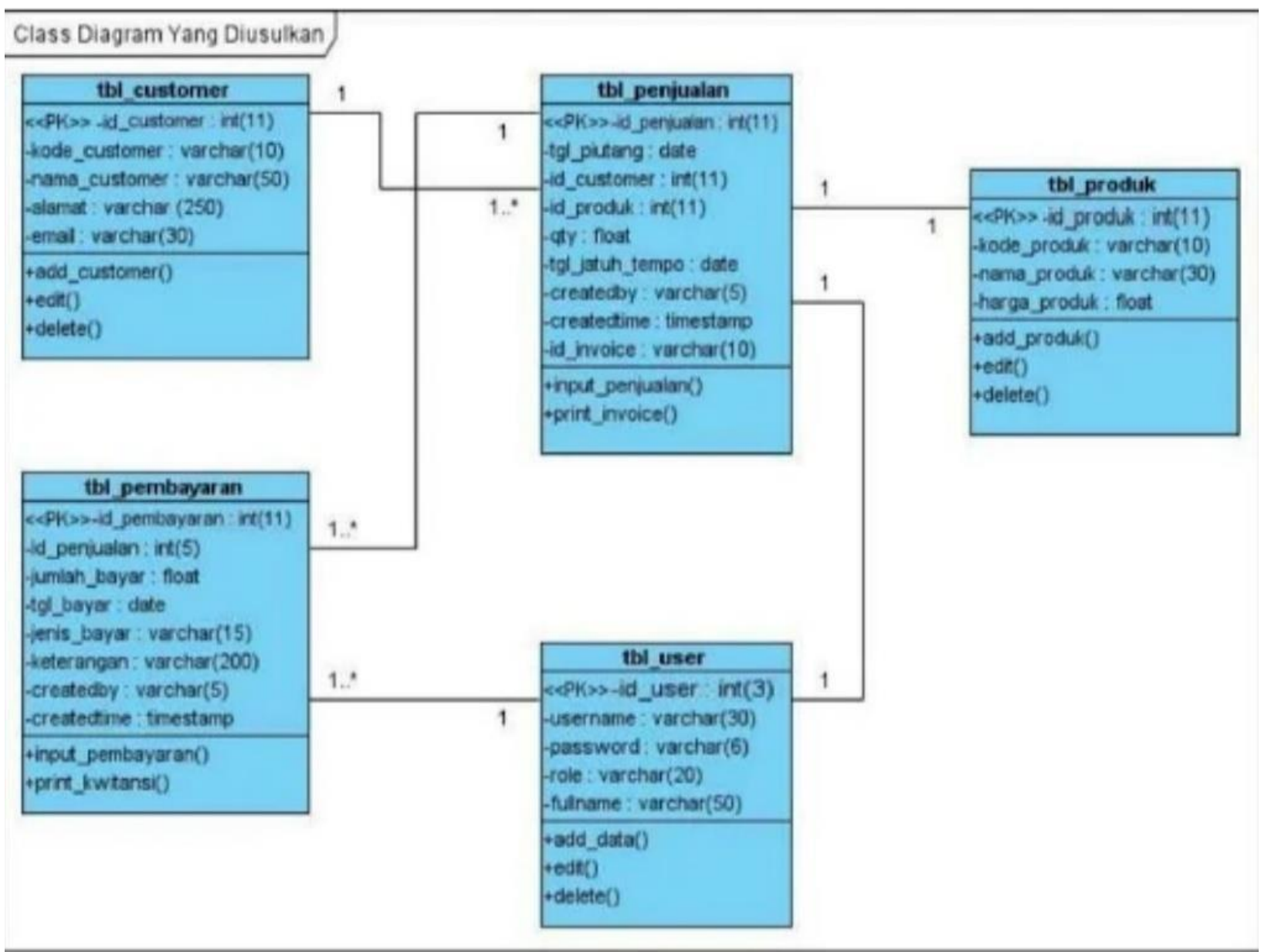


Gambar 5 Class Diagram yang diusulkan

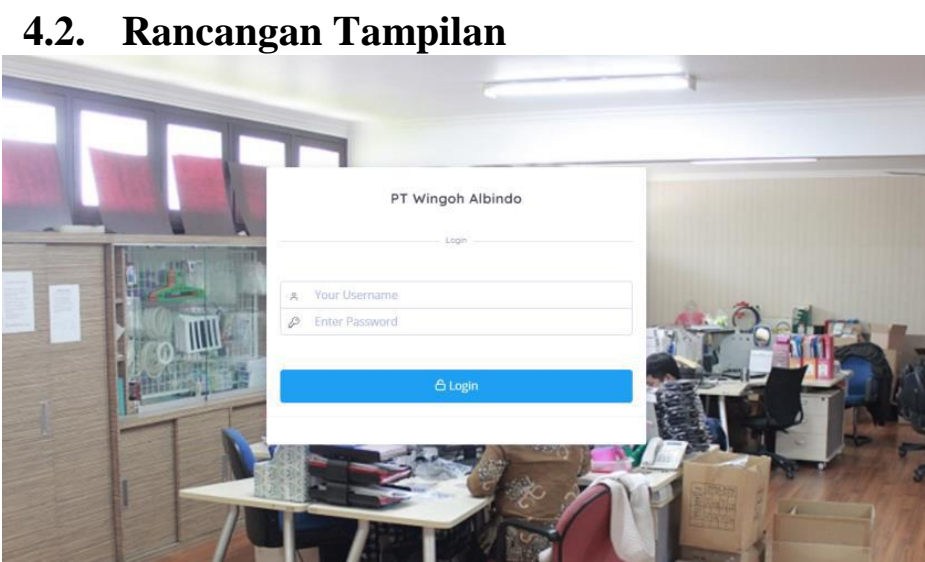

Gambar 6. Tampilan Login

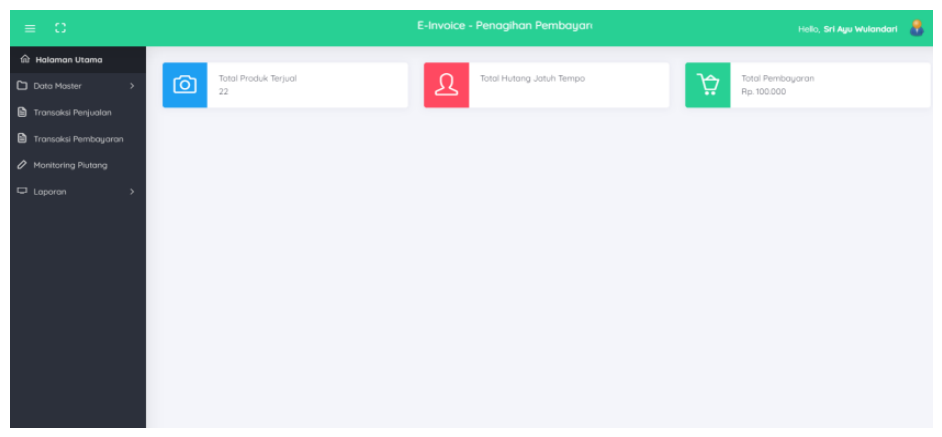

Gambar 7 Tampilan Menu Halaman Utama

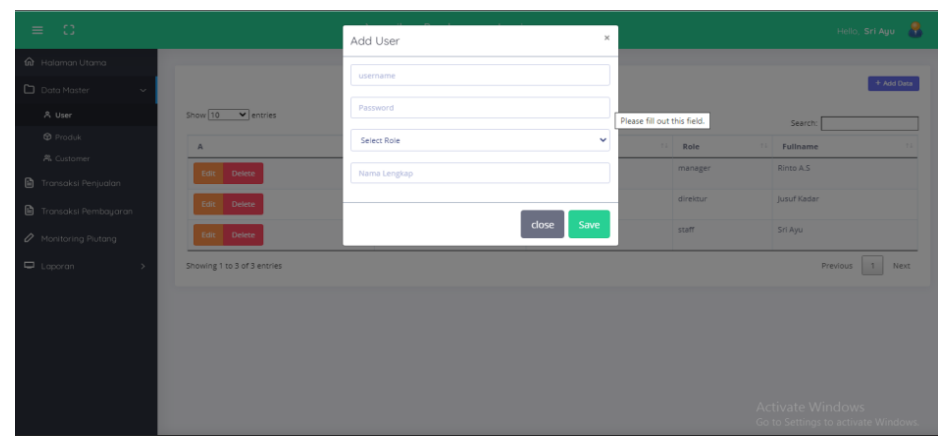

Gambar 7 Tampilan Menu Add and User

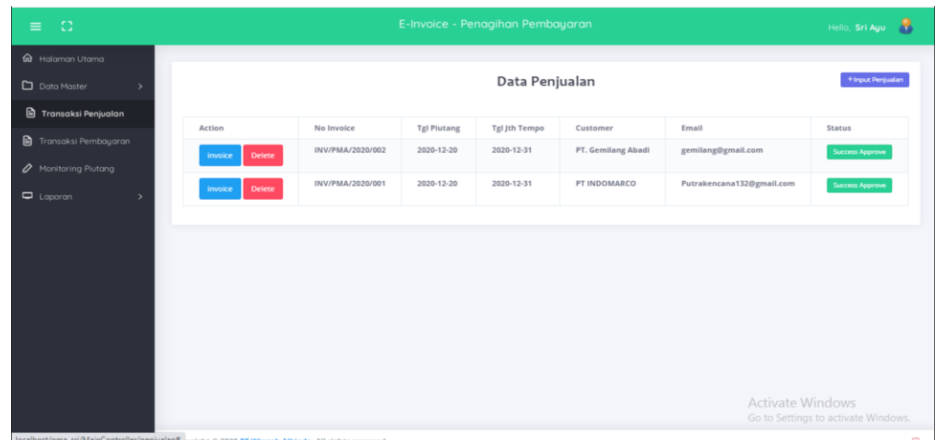

Gambar 8 Tampilan Menu Data Penjualan 


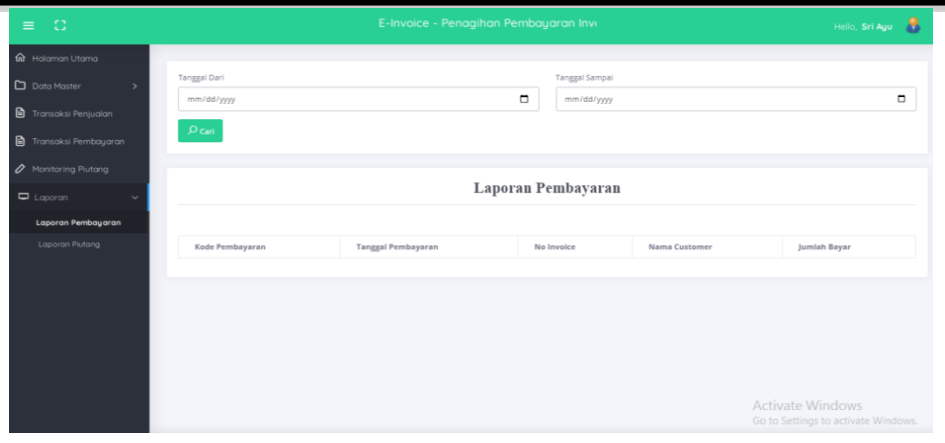

Gambar 9 Tampilan Menu Laporan Pembayaran

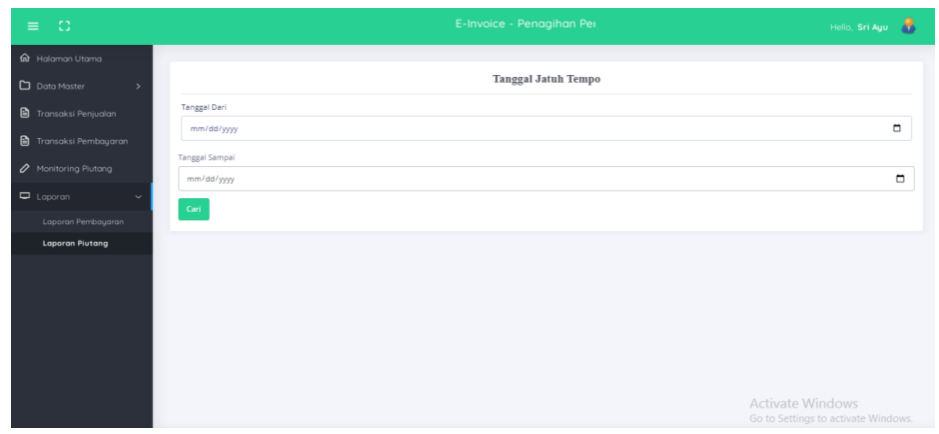

Gambar 10 Tampilan Menu Tanggal Jatuh Tempo

\section{KESIMPULAN}

Berdasarkan dari hasil penelitian yang dilakukan pada PT Wingoh Albindo, tentang monitoring pembayaran piutang dapat disimpulkan bahwa proses monitoring pembayaran piutang pada PT Wingoh Albindo yang sedang berjalan saat ini masih semi komputerisasi yaitu dengan microsoft excel. Sehingga proses untuk transaksi penjualan, pembayaran piutang, laporan penjualan dan laporan piutang juga, masih menggunakan microsoft excel sehingga membutuhkan waktu yang lama untuk menyelesaikan dan mengelola rekap pembayaran piutang karena masih manual dan tidak terlepas dari kesalahan dalam proses pengolahannya. Dimana untuk prosesnya staff marketing menerima PO dari customer, setelah itu staff gudang membuat surat jalan, staff A.R membuat invoice, setelah barang dikirim, customer melakukan pembayaran, staff A.R merekap laporan piutang yang akan diberikan ke Manager. Permasalahan yang sering terjadi pada proses monitoring pembayaran piutang saat ini yaitu dimana keluhan staff A.R untuk dapat membedakan piutang customer yang akan jatuh tempo dan yang sudah terlambat untuk membayar. Untuk merancang aplikasi ini menggunakan bahasa pemrograman PHP, Database Server MySQL, sublime text 2, framework codeigniter dan web server dengan XAMPP. Dimana prosesnya Staff A.R dapat melakukan login, menambah user, produk, data customer, transaksi penjualan, pembayaran, monitoring, laporan dan logout. Sedangkan Manajer bisa melakukan login, menampilkan dashboard, transaksi penjualan, pembayaran, laporan dan logout. 


\section{DAFTAR PUSTAKA}

[1] Abdulloh, Rohi. 2016. "Easy \& Simple Web Programming”. Jakarta: PT. Elex Media Komputindo.

[2] Agusvianto, Hendra. 2017. "Sistem Informasi Inventory Gudang Untuk Mengontrol Persediaan Barang Pada Gudang". Studi Kasus: PT. Alaisys Sidoarjo. Journal Information Engineering and Educational Technology (JIEET). 01(01). ISSN: 2549869X.

[3] Ahsyar, Khairil., Tengku. Abd Rahman. 2018: 142-149. "Sistem Monitoring Piutang Dan Inventori Barang Di PT. ANugrah Citra Pestindo". Jurnal Ilmiah Rekayasa dan Manajemen Sistem Informasi, Vol. 4 No. 2. UIN SUSKA Riau. Agustus 2018. E-ISSN 2502-8995, p-ISSN 2460-8181.

[4] Amrullah, Agit., Rifda Faticha Alfa., Danang Sutedjo., Renna Yanwastika Ariyana., Hendi S dan Eri Sasmita Susanto. 2016. "Kajian Kebutuhan Perangkat Lunak Sistem Informasi Penilaian Prestasi Kerja Pegawai Pada Fakultas Adab dan ilmu Budaya Universitas Islam negeri Sunan Kalijaga Yogyakarta”. Yogyakarta: Seminar Nasional Teknologi Informasi dan Multimedia. ISSN: 2302-3805.

[5] Amrullah, Agit., Rifda Faticha Alfa., Danang Sutedjo., Renna Yanwastika Ariyana., Hendi S dan Eri Sasmita Susanto. 2016. "Kajian Kebutuhan Perangkat Lunak Sistem Informasi Penilaian Prestasi Kerja Pegawai Pada Fakultas Adab dan Ilmu Budaya Universitas Islam Negeri Sunan Kalijaga Yogyakarta”. Yogyakarta: Seminar Nasional Teknologi Informasi dan Multimedia. ISSN : 2302-3805.

[6] Andika Jaya, Kriyan., Novi Safriadi., Anggi Perwitasari. 2018 : 22-27. "Aplikasi Monitoring dan Evaluasi Kinerja Aparatur di Kejaksaan Negeri

[7] 122

[8] Mempawah". Jurnal Sistem Informasi dan Teknologi Informasi. Kalimantan : Universitas Tanjungpura. Vol.6, No.1, Januari 2018. ISSN : 2460-3562.

[9] Anhar. 2016. "Kumpulan Source Code Visual Basic 6.0 untuk Skripsi”. PT Elex Media Komputindo: Jakarta.

[10] Aris., Indah Puspita Sari., Desi Artriyani., Tia Cahya Restiqi. 2016. "DESAIN APLIKASI SISTEM INFORMASI PENJUALAN SECARA ONLINE PADA PT. ULTINET INDONESIA”. Tangerang: STMIK Raharja ISSN: 2302-3805.

[11] Astuti, Kondar Siahaan Dui dan Joni Devitra. 2017. "Analisis dan Perancangan Sistem Informasi Simpan Pinjam pada Koperasi Pegawai Negeri Iain Sultan Thaha Saifuddin Jambi”. Jambi: Jurnal Manajemen Sistem Informasi STIKOM Dinamika Bangsa Jambi. Vol.2 No.2:516.

[12] Azizah, Nur, Lina Yuliana dan Elsa Juliana. 2017. "Rancang Bangun Sistem Informasi Penggajian Karyawan Harian Lepas pada PT. Flex Indonesia. Jurnal SENSI. Tangerang”. Perguruan Tinggi Raharja. ISSN: 2461-1409. Vol.3 No.1-Februari 2017.Maniah dan Dini Hamidin. 2017 : 2. "Analisis Dan Perancangan Sistem Informasi". Yogyakarta: Deepublish.

[13] Azizah, Nur., Dedeh Supriyati., SIto Fairuz Aminah Mustapha., Holly Yang. "The Role of Web Based Accounting Online System 2.0 as the Company's Income and Expense Management". Aptisi Transactions on Agriculture, Vol 1 No 1. Neliti. ISSN: $2622-$ 6812. Page 44-49. 